\title{
KEBERLANJUTAN RANTAI PASOK INDUSTRI KECIL DAN MENENGAH (IKM) ALAS KAKI DI KABUPATEN DAN KOTA BOGOR
}

\section{SUPPLY CHAIN SUSTAINABILITY OF FOOTWEAR SMALL AND MEDIUM ENTERPRISES (SMES) IN DISTRICT AND CITY OF BOGOR}

\author{
Wilda Sukmawati $^{1,3)^{*}}$, Machfud $^{2)}$, Ono Suparno ${ }^{2)}$, Aji Hermawan ${ }^{2)}$ \\ ${ }^{1)}$ Program Studi Teknologi Industri Pertanian, Fakultas Teknologi Pertanian, Institut Pertanian Bogor \\ Kampus IPB Darmaga, Bogor 16680 \\ e-mail: wildsn07@gmail.com \\ 2) Departemen Teknologi Industri Pertanian, Fakultas Teknologi Pertanian, Institut Pertanian Bogor \\ ${ }^{3)}$ Politeknik STMI Jakarta Kementerian Perindustrian Republik Indonesia \\ Makalah: Diterima 26 November 2019; Diperbaiki 13 Maret 2020; Disetujui 30 Maret 2020
}

\begin{abstract}
Measurement of supply chain sustainability in the footwear industry is limited to measurements on craftsmen as footwear makers in the District and City of Bogor. The purpose of this study was to obtain a footwear industry supply chain sustainability index in the District and City of Bogor as an industrial centre in the West Java region. The method approach taken was Multidimensional Scaling (MDS) using Rapfish software. This study analyzed three dimensions, namely economic, social and environment. The indicators used for the economic dimension were net profit, sales targets, production capacity, labour income, product quality, market access, investment for the environmental improvement, research and technology development. Indicators measured for the social dimension were employment opportunities for the local workers, human reource skills, easiness access to health, use of equipment, work safety, workplace quality, air quality of production rooms, workforce training, number of products returned, and certification in the social field. On the environmental dimension, the indicators measured were the reduction in the amount of energy used, the use of environmentally friendly materials, the level of waste management, measurement and reduction of emissions produced, certification in the environmental field, use of materials from local suppliers. The results of measurement of the footwear industry sustainability indexes were less sustainable for the economic and social dimensions, whereas for the environment dimension indexed was not sustainable. In leverage analysis, indicators that influenced to increase the index for the economic dimension were market access and labour income, the social dimension were the quality of the production room air and the use of safety equipment, and the environmental dimension were the level of waste management, measurement and emission reduction.
\end{abstract}

Keywords: sustainability. footwear, $M D S$

\section{ABSTRAK}

Pengukuran keberlanjutan rantai pasok di industri alas kaki dibatasi pada pengukuran yang dilakukan terhadap pengrajin sebagai pembuat alas kaki di kabupaten dan kota Bogor. Tujuan dari penelitian ini adalah mendapatkan indeks keberlanjutan rantai pasok industri alas kaki di kabupaten dan kota Bogor sebagai sentra industri di wilayah Jawa Barat. Pendekatan metode yang dilakukan adalah Multidimensional Scaling (MDS) dengan menggunakan software Rapfish. Penelitian ini menganalisa tiga dimensi yang diukur, yaitu ekonomi, sosial dan lingkungan. Indikator yang digunakan untuk dimensi ekonomi adalah Net profit, target penjualan, kapasitas produksi, pendapatan tenaga kerja, mutu produk, akses pasar, Investasi untuk perbaikan lingkungan, penelitian dan pengembangan teknologi. Indikator yang diukur untuk dimensi sosial adalah peluang kerja bagi tenaga lokal, keterampilan SDM, kemudahan akses kesehatan, penggunaan alat, keselamatan kerja, kualitas tempat kerja, kualitas udara ruangan produksi, pelatihan tenaga kerja, jumlah produk yang dikembalikan, sertifikasi dalam bidang sosial. Pada dimensi lingkungan, indikator yang diukur adalah pengurangan jumlah energi terpakai, penggunaan bahan ramah lingkungan, tingkat pengelolaan limbah, pengukuran dan pengurangan emisi yang dihasilkan, sertifikasi dalam bidang lingkungan, penggunaan bahan dari pemasok lokal. Hasil pengukuran keberlanjutan alas kaki diperoleh indeks kurang berlanjut untuk dimensi ekonomi dan sosial, sedangkan untuk dimensi lingkungan berindeks tidak berlanjut. Dalam analisis leverage, indikator yang berpengaruh untuk meningkatkan indeks untuk dimensi ekonomi adalah akses pasar dan pendapatan tenaga kerja, dimensi sosial adalah kualitas udara ruangan produksi dan penggunaan alat keselamatan kerja, dan dimensi lingkungan adalah tingkat pengelolaan limbah, pengukuran dan pengurangan emisi.

Kata kunci : alas kaki, keberlanjutan, MDS 


\section{PENDAHULUAN}

Salah satu sentra alas kaki yang berbentuk usaha mikro, industri kecil dan menengah (IKM) di Jawa Barat terdapat di daerah Bogor. Lokasi IKM merupakan rumah-rumah pribadi dan biasanya terdiri dari 2-7 pekerja. Pemilik dan pekerja IKM sebagian besar memiliki latar belakang pendidikan dasar (SD, SMP atau SMA) yang mendedikasikan hidupnya untuk memproduksi alas kaki secara turun temurun. Produsen alas kaki IKM juga disebut dengan pengrajin. IKM alas kaki kesulitan dalam mendapatkan modal, khususnya dari perbankan karena IKM sering tidak melakukan pembayaran sehingga perbankan menolak permohonan pengajuan pinjaman dari perbankan.

Selain itu, tidak adanya organisasi induk dan koperasi juga membuat IKM alas kaki kesulitan untuk mendapatkan modal. Keterbatasan modal membuat IKM sulit berkembang, seperti kesulitan dalam mengembangkan teknologi penghasil alas kaki dan mendapatkan bahan baku dengan kualitas yang baik. Upah pekerja yang semakin meningkat karena semakin banyaknya jumlah pabrik alas kaki yang menyebabkan peningkatan jumlah permintaan pekerja, sehingga untuk mendapatkan pekerja IKM harus membayar upah yang lebih besar dibandingkan dengan pabrik. Selain itu, pekerja IKM biasanya bersifat turun temurun yang berasal dari keluarga, tetapi perkembangan jaman menyebabkan generasi saat ini tidak mau melakukan produksi alas kaki. Kualitas produk yang dihasilkan oleh IKM termasuk dalam kualitas yang rendah sehingga sulit untuk bersaing dipasaran. Jumlah IKM dan pabrik alas kaki yang meningkat juga menyebabkan persaingan alas kaki di pasaran semakin ketat.

Di dalam memproduksi alas kaki membutuhkan pemenuhan aliran material, informasi, pembayaran dan jasa dari bahan baku sampai ke konsumen akhir. Perusahaan membutuhkan suatu keunggulan yang kompetitif melalui perencanaan yang strategi yang tepat dalam menjaga keberlangsungan bisnisnya. Strategi bersaing dan strategi rantai pasokan memiliki hubungan yang kuat dengan keberlanjutan. Tergantung pada lingkungan bisnis, penawaran dan permintaan karakteristik eksternal, perusahaan perlu menentukan strategi perusahaan dan strategi bersaing. Untuk mencapai keunggulan kompetitif yang diharapkan, maka perlu untuk menentukan strategi rantai pasokan yang akan dilaksanakan dan menghasilkan berbagai operasi rantai suplai (Cohen dan Roussel, 2005). Menurut Chopra dan Meindl (2007) dan Vorst (2004), menyatakan bahwa manajemen rantai pasok merupakan salah satu aspek yang dapat digunakan dalam menghasilkan keunggulan kompetitif. Oleh karenanya, penyusunan dan perbaikan rantai pasok industri alas kaki yang sudah ada menjadi penting untuk dilakukan, agar dihasilkan keberlanjutan industri alas kaki sehingga kualitas dan kuantitas alas kaki yang dihasilkan oleh industri di Indonesia dapat bersaing baik dipasaran nasional maupun internasional.

\section{METODE PENELITIAN}

Penelitian ini diawali dengan kajian pustaka dan memulai mengidentifikasi kondisi terkini (current state) untuk mengkaji kompleksitas yang terjadi di rantai pasok industri hilir karet, khususnya industri alas kaki. Jumlah IKM yang menjadi objek penelitian ini sebanyak 21 IKM di tiga kecamatan di Bogor. Data primer di peroleh dari pendapat para pakar dan wawancara mendalam dengan berbagai pihak terkait baik dari kalangan pemerintah, pelaku industri maupun akademisi. Metode yang digunakan dalam menganalisis keberlanjutan rantai pasok alas kaki adalah Metode Multidimensional Scaling (MDS). MDS digunakan untuk menentukan indeks berkelanjutan secara aggregate yang mencakup analisis leverage dan analisis Montecarlo. Indikator dan atribut keberlanjutan didapatkan dari kajian literatur dan keadaan yang sebenarnya dari objek penelitian, yang kemudian didiskusikan bersama pakar sehingga didapatkan indikator yang dapat mewakili keadaan industri. Dimensi yang diamati yaitu dimensi ekonomi, sosial dan lingkungan.

Metode MDS digunakan dalam teknis ordinasi rapfish yang dimodifikasi dari program rapfish yang dikembangkan oleh Fisheries Centre, University of Columbia. Tahapan analisis keberlanjutan dengan metode MDS dimulai dengan menentukan atribut pada setiap dimensi keberlanjutan dan mendefinisikannya melalui kajian pustaka, pengamatan lapangan, dan diskusi dengan beberapa pakar. Daftar pertanyaan mengarah pada seluruh data dan informasi mengenai kegiatan industri alas kaki dalam rangka mengisi kolom skor bagi atribut-atribut dalam Rapfish yang telah disiapkan. Kolom skor atribut yang tidak dapat diisi oleh informasi yang diperoleh melalui observasi langsung dan wawancara, maka dilakukan pencaharian informasi yang terkait dengan atribut tersebut melalui berbagai saluran informasi seperti penelusuran pustaka dan laporanlaporan dari lembaga-lembaga terkait. Kolom atribut untuk masing-masing dimensi dapat dilihat pada Tabel 1. Penilaian pada setiap atribut dalam skala ordinal (scoring) berdasarkan hasil survei lapangan dan dan penilaian pakar untuk menentukan posisi status keberlanjutan pada setiap dimensi dalam skala indeks keberlanjutan dilakukan analisis ordinasi. 
Tabel 1. Atribut keberlanjutan dimensi ekonomi, sosial, lingkungan industri alas kaki

\begin{tabular}{|c|c|c|c|c|}
\hline No. & Atribut & Kategori & Rantang Nilai & Skor \\
\hline 1. & Net profit & $\begin{array}{l}\text { Merugi, sangat rendah, rendah, } \\
\text { sedang, tinggi }\end{array}$ & & $\begin{array}{c}0,1,2 \\
3,4\end{array}$ \\
\hline 2. & Target pejualan & $\begin{array}{l}\text { Sangat rendah, rendah, sedang, } \\
\text { cukup tinggi, tinggi }\end{array}$ & $\begin{array}{l}\mathrm{TP}<60 \%, 60 \%<\mathrm{TP} \leq 70 \\
\%, 70 \%<\mathrm{TP} \leq 80 \%, 80 \\
\%<\mathrm{TP} \leq 90 \%, \mathrm{TP}>90 \%\end{array}$ & $\begin{array}{l}0,1,2 \\
\quad 3,4\end{array}$ \\
\hline 3. & Kapasitas produksi & Menurun, tetap, meningkat & & $0,1,2$ \\
\hline 4. & $\begin{array}{l}\text { Pendapatan tenaga } \\
\text { kerja }\end{array}$ & $\begin{array}{l}\text { Kurang dari UMR, setara UMR, } \\
\text { lebih dari UMR }\end{array}$ & & $0,1,2$ \\
\hline 5. & Mutu produk & Rendah, sedang, cukup tinggi, tinggi & & $0,1,2,3$ \\
\hline 6. & Akses pasar & Sulit, agak sulit, mudah & & $0,1,2$ \\
\hline 7. & $\begin{array}{l}\text { Investasi untuk } \\
\text { perlindungan } \\
\text { lingkungan }\end{array}$ & $\begin{array}{l}\text { Belum melakukan investasi, sudah } \\
\text { melakukan investasi }\end{array}$ & & 0,1 \\
\hline 8. & $\begin{array}{l}\text { Penelitian dan } \\
\text { pengembangan } \\
\text { teknologi }\end{array}$ & $\begin{array}{l}\text { Jarang melakukan pengembangan, } \\
\text { agak sering, sering }\end{array}$ & & $0,1,2$ \\
\hline 1. & $\begin{array}{l}\text { Peluang kerja bagi } \\
\text { tenaga lokal }\end{array}$ & Kecil, sedang, besar & & $0,1,2$ \\
\hline 2. & Keterampilan SDM & $\begin{array}{l}\text { Agak terampil, cukup terampil, } \\
\text { terampil, sangat terampil }\end{array}$ & & $\begin{array}{c}0,1,2 \\
3,4\end{array}$ \\
\hline 3. & $\begin{array}{l}\text { Kemudahan akses } \\
\text { kesehatan }\end{array}$ & Sulit, mudah & $\begin{array}{l}\text { Tidak terdapat klinik pada } \\
\text { lingkungan kerja dan tidak } \\
\text { adanya asuransi Kesehatan, } \\
\text { Terdapat klinik pada } \\
\text { lingkungan kerja dan } \\
\text { industri memberikan } \\
\text { asuransi kesehatan pada } \\
\text { semua pekerja }\end{array}$ & 0,1 \\
\hline 4. & $\begin{array}{l}\text { Penggunaan alat } \\
\text { keselamatan kerja }\end{array}$ & $\begin{array}{l}\text { Belum menggunakan, sudah } \\
\text { menggunakan }\end{array}$ & & 0,1 \\
\hline 5. & Kualitas tempat kerja & Buruk, agak buruk, sedang, baik & & $0,1,2,3$ \\
\hline 6. & $\begin{array}{l}\text { Pellatihan tenaga } \\
\text { kerja }\end{array}$ & Jarang, agak sering, sering & & $0,1,2$ \\
\hline 7. & $\begin{array}{l}\text { Jumlah produk yang } \\
\text { dikembalikan }\end{array}$ & Sering, agak sering, jarang & & $0,1,2$ \\
\hline 8. & $\begin{array}{l}\text { Kesesuaian dengan } \\
\text { peraturan tenaga } \\
\text { kerja }\end{array}$ & Belum sesuai, sudah sesuai & & 0,1 \\
\hline 1. & $\begin{array}{l}\text { Pengurangan jumlah } \\
\text { energi terpakai }\end{array}$ & $\begin{array}{l}\text { Belum mengurangi, sudah } \\
\text { mengurangi }\end{array}$ & & 0,1 \\
\hline 2. & $\begin{array}{l}\text { Penggunaan bahan } \\
\text { ramah lingkungan }\end{array}$ & $\begin{array}{l}\text { Belum menggunakan bahan baku } \\
\text { bersertifikasi, sudah menggunakan } \\
\text { bahan baku bersertifikasi }\end{array}$ & & 0,1 \\
\hline 3. & $\begin{array}{l}\text { Tingkat pengelolaan } \\
\text { limbah }\end{array}$ & $\begin{array}{l}\text { Membuang langsung limbah padat, } \\
\text { tidak memisahkan limbah padat, } \\
\text { memisahkan limbah padat sesuai } \\
\text { kegunaan }\end{array}$ & & $0,1,2$ \\
\hline 4. & $\begin{array}{l}\text { Pengurangan dan } \\
\text { pengelolaan emisi }\end{array}$ & $\begin{array}{l}\text { Belum melakukan pengurangan } \\
\text { energi, melakukan pengurangan } \\
\text { energi pada peralatan pembantu } \\
\text { produksi, melakukan pengurangan } \\
\text { energi pada perlatan produksi, Sudah } \\
\text { melakukan pengurangan energi } \\
\text { secara menyeluruh }\end{array}$ & & $0,1,2,3$ \\
\hline 5. & $\begin{array}{l}\text { Sertifikat dibidang } \\
\text { lingkungan }\end{array}$ & $\begin{array}{l}\text { Belum memiliki sertifikasi, sudah } \\
\text { memiliki sertifikasi }\end{array}$ & & 0,1 \\
\hline 6. & $\begin{array}{l}\text { Penggunaan bahan } \\
\text { dari pemasok lokal }\end{array}$ & $\begin{array}{l}\text { Belum menggunakan bahan dari } \\
\text { pemasok lokal, menggunakan bahan } \\
\text { dari pemasok lokal dan internasional, } \\
\text { Sudah menggunakan bahan dari } \\
\text { pemasok lokal }\end{array}$ & & $0,1,2$ \\
\hline
\end{tabular}


Menurut Alder et al. (2000) teknik ordinasi (penentuan jarak) dalam MDS didasarkan pada euclidian distance yang dalam ruang berdimensi $n$ dapat ditulis sebagai berikut:

$$
\mathrm{d}=\sqrt{\left(\left|X_{1}-X_{2}\right| 2+\left|Y_{1}-Y_{2}\right| 2+\left|Z_{1}-Z_{2}\right| 2+\cdots\right)} \ldots
$$

Nilai tersebut kemudian diaproksimasi dengan meregresikan jarak euclidian (dij) dari titik $\mathrm{i}$ ke titik $\mathrm{j}$ dengan titik asal ( $\delta \mathrm{ij}$ ) sebagaimana persamaan di bawah ini:

$\operatorname{dij}=\alpha+\beta \delta \mathrm{ij}+\varepsilon$

Selanjutnya dilakukan sensivity analysis (analisis leverage) untuk menentukan peubah yang sensitif mempengaruhi keberlanjutan dan untuk memperhitungkan dimensi ketidakpastian dilakukan analisis Montecarlo. Pada proses analisis dengan metode MDS ditentukan nilai stress dan koefisien determinasi (R2). Nilai stress yang rendah menunjukkan good fit, sementara nilai stress yang tinggi menunjukkan kondisi sebaliknya. Nilai stress dapat dirumuskan:

$$
S=\sqrt{\frac{1}{m}} \sum_{k=1}^{m}\left|\frac{\sum_{i} \sum_{j}\left(d_{g k}^{2}-o_{g j}^{2}\right)^{2}}{\sum_{i} \sum_{j} o_{i j k}^{4}}\right|
$$

Apabila nilai stress kurang dari 0,25 menunjukkan bahwa hasil analisis telah cukup baik. Nilai stress dan koefisien determinasi (R2) menentukan perlu tidaknya penambahan peubah untuk memastikan bahwa peubah yang digunakan telah mewakili sifat obyek yang dibandingkan. Atribut yang sensitif diperoleh berdasarkan hasil analisis leverage yang terlihat pada perubahan Root Mean Square (RMS) ordinasi pada sumbu X. Semakin besar RMS maka semakin sensitif peranan atribut tersebut terhadap peningkatan status keberlanjutan. Penentuan status keberlanjutannya dilakukan pengelompokkan terhadap nilai indeks dengan selang indeks 0-25,00 (buruk), 25,01-50,00 (kurang), 50,01-75,00 (cukup), dan 75,01-100 (baik).

\section{HASIL DAN PEMBAHASAN}

\section{Indikator Keberlanjutan Industri IKM}

Saeed dan Kersten

(2017),

mengelompokkan indikator yang bisa digunakan untuk mengukur rantai pasok berkelanjutan menjadi tiga dimensi, yaitu ekonomi, sosial dan lingkungan. Indikator tersebut didapatkan dari berbagai macam standar pengukuran seperti, UNGC, ISO 14001, SA 8000, ILO, ISO 14031, GRI, EMAS, OECD, ISO 26000, IchemE, Green SCOR, OHSAS 18001, yang ditunjukkan oleh Tabel 1. GRI merupakan satusatunya standar pengukuran yang memiliki semua indikator yang dibutuhkan untuk mengukur rantai pasok berkelanjutan. GRI atau global reporting initiative adalah organisasi untuk mengukur keberlanjutan suatu perusahaan atau industri menggunakan standar yang dimilikinya pada dimensi ekonomi, sosial dan lingkungan dan hasil yang didapatkan kemudian dipublikasikan untuk kepentingan publik. Masing-masing kategori indikator bisa diperluas untuk mendapatkan indikator yang paling sesuai dengan keadaan yang sebenarnya.

Tabel 2. Kategori indikator berkelanjutan

\begin{tabular}{cl}
\hline $\begin{array}{c}\text { Dimensi } \\
\text { keberlanjutan }\end{array}$ & \multicolumn{1}{c}{ Kategori indikator } \\
\hline Ekonomi & $\begin{array}{c}\text { Keuntungan dan stabilitas } \\
\text { Distribusi pendapatan } \\
\text { Daya saing pasar } \\
\text { Pengeluaran untuk } \\
\text { berkelanjutan }\end{array}$ \\
\hline Sosial & Hak asasi manusia dan \\
& anti korupsi \\
& Sumber daya manusia \\
& Kesehatan dan keamanan \\
& Pendidikan dan pelatihan \\
& Permasalahan konsumen \\
& Kepatuhan sosial \\
& Efisiensi energi \\
& Efisiensi bahan \\
& Pengelolaan air \\
& Pengelolaan limbah \\
& Pengelolaan emisi \\
& Penggunaan lahan \\
& Kepatuhan lingkungan \\
& Penilaian pemasok \\
\hline Lingkungan &
\end{tabular}

Dimensi ekonomi dalam keberlanjutan rantai pasok menggambarkan aliran dan distribusi finansial pelaku dalam rantai pasok. Sumber finansial tersebut kemudian akan digunakan untuk memperbaiki dimensi sosial dan lingkungan sehingga menjadi keberlanjutan. Menurut Saeed dan Kersten (2017), kategori dalam dimensi ekonomi dibagi menjadi empat. Keuntungan dan stabilitas menggambarkan kesehatan finansial suatu organisasi, yang ditunjukkan oleh pendapatan yang diterima, keuntungan yang didapatkan, dan total produk yang dihasilkan. Distribusi pendapatan menggambarkan jumlah pendapatan yang diterima pekerja, jumlah pajak yang dibayarkan ke negara, investasi yang dilakukan untuk perbaikan, dan biaya produksi. Daya saing pasar menggambarkan kemampuan suatu organisasi untuk bersaing dengan organisasi lainnya dengan produk yang sama dipasaran. Pengeluaran untuk berkelanjutan adalah pengeluaran yang dilakukan oleh organisasi untuk menjadikan organisasi menjadi berkelanjutan, baik penelitian, pengembangan ataupun sertifikasi. 
Menurut Saeed dan Karsten (2017), dimensi sosial menggambarkan cara organisasi organisasi bertanggungjawab secara sosial dan mengatur sumberdaya manusia yang dimiliki. Hak asasi manusia dan anti korupsi menggambarkan informasi tentang korupsi dan pelanggaran terhadap hak asasi manusia, yang ditunjukkan oleh adanya diskriminasi, pemaksaan dan penggunaan anak sebagai pekerja, serta pelanggaran terhadap kebebasan. Industri alas kaki khususnya skala usaha kecil atau IKM merupakan usaha turun temurun di suatu kawasan. Dahulu, banyak pekerja yang masih termasuk dalam usia anak-anak menjadi pekerja di IKM alas kaki untuk membantu orangtua. Sebab, biasanya para pekerja di IKM alas kaki memulai bekerja pada usia yang sangat muda atau belum lulus pendidikan sekolah dasar, baik karena kemauan sendiri atau karena terpaksa membantu orangtua karena memiliki keterbatasan secara finansial. Keterbatasan secara finansial juga membuat kesulitan untuk melanjutkan pendidikan. Namun, semakin berkembangnya kemudahan untuk mengakses pendidikan saat ini, membuat usaha alas kaki bukan usaha turun temurun yang harus dilakukan saat usia muda. Anak-anak di kawasan IKM alas kaki saat ini lebih memilih untuk menyelesaikan pendidikan dasar 9 tahun dan mencari pekerjaan selain usaha alas kaki atau diluar kawasan IKM alas kaki. Akan tetapi, masih ada juga beberapa anak yang memilih untuk melanjutkan usaha alas kaki orang tuannya. Kemudahan akses pendidikan selain berdampak baik bagi anak-anak di kawasan alas kaki, juga memberikan dampak buruk karena semakin banyak IKM yang tidak memiliki penerus dan terancam menutup usahanya, sehingga jumlah usaha alas kaki dalam suatu kawasan menjadi semakin berkurang.

Dimensi lingkungan merupakan dimensi yang memiliki standar pengukuran paling banyak dibandingkan dengan dimensi lainnya, sebab dimensi lingkungan merupakan dimensi yang sangat menggambarkan keberlanjutan. Dimensi lingkungan menggambarkan perilaku industri dalam menjaga dan melestarikan lingkungan di sekitarnya. Dengan begitu, industri bukan hanya memproduksi produk yang dihasilkan, tetapi juga ikut memikirkan bagai mana cara melestrarikan dan mengurangi dampak negatif yang ditimbulkan dari produk yang dihasilkan. Akan tetapi, keberlanjutan dimensi lingkungan pada industri alas kaki memiliki indikator yang sangat terbatas. Hal tersebut terjadi karena industri alas kaki adalah industri padat karya yang lebih banyak menggunakan tenaga manusia dibandingkan dengan sumber-sumber energi. Energi yang digunakan hanya energi listrik untuk menjalankan mesin.

Kategori indikator untuk pengukuran rantai pasok berkelanjutan yang sudah didapatkan kemudian disesuaikan dengan keadaan yang sebenarnya pada industri alas kaki. Indikator yang menggambarkan keberlanjutan dari masing-masing dimensi didapatkan dari observasi lapang, pengkajian pustaka dan diskusi mendalam bersama pakar dibidang alas kaki. Indikator yang digunakan untuk mengukur keberlanjutan IKM alas kaki dibahas pada masing-masing dimensi.

\section{Dimensi Ekonomi}

Dimensi ekonomi dalam keberlanjutan rantai pasok menggambarkan aliran dan distribusi finansial pelaku dalam rantai pasok. Sumber finansial tersebut kemudian akan digunakan untuk memperbaiki dimensi sosial dan lingkungan sehingga menjadi keberlanjutan. Berdasarkan kategori indikator keuntungan dan stabilitas, distribusi pendapatan, daya saing pasar, pengeluaran untuk berkelanjutan yang disesuaikan dengan kondisi di lapangan dan dengan melakukan brainstorming dengan pelaku industri yang nenahami tentang keberlanjutan, pengukuran keberlanjutan dimensi ekonomi didalam industri IKM di Bogor terdiri atas 8 indikator, yaitu: 1) net profit margin; 2) target penjualan; 3) kapasitas produksi; 4) pendapatan tenaga kerja; 5) mutu produk; 6) akses pasar; 7) investasi untuk perbaikan lingkungan; dan 8) penelitian dan pengembangan teknologi. Indikator net profit per unit usaha adalah keuntungan bersih setelah pajak yang diperoleh oleh setiap unit usaha. Net profit per unit menjadi indikator penting pada dimensi ekonomi karena berpengaruh terhadap kinerja komponen sistem lainnya. Net profit yang diterima sebagai acuan untuk melakukan beberapa kegiatan penting yang mempengaruhi keberlanjutan, seperti kegiatan penanganan bahan baku, partnership, maupun pengelolaan limbah.

Pengkategorian nilai indikator net profit per unit usaha dimaksudkan untuk menilai tingkat keuntungan bersih yang diterima oleh industri alas kaki. Target penjualan adalah nilai penjualan produk yang diharapkan. Indikator ini dapat menunjukkan perkembangan aktivitas ekonomi yang berkaitan dengan profitabilitas industri. Hal ini mengindikasikan bahwa industri telah berupaya melakukan efisiensi proses produksi dan peningkatan nilai tambah produk agar pencapaian target penjualan semakin meningkat. Kapasitas produksi menunjukkan jumlah alas kaki yang diproduksi setiap kurun waktu tertentu. Berdasarkan pabrik dan IKM yang sudah dikunjungi, kapasitas produksi menurun dibandingkan sebelumnya. Kapasitas produksi juga menentukan kegiatan yang dilakukan pada suatu usaha.

Pendapatan tenaga kerja menjadi salah satu indikator dalam dimensi sosial karena mempunyai peranan penting dalam mempengaruhi daya tarik tenaga kerja untuk bekerja pada industri. Apabila pendapatan tenaga kerja sangat rendah, maka potensi terjadinya perpindahan tenaga kerja menuju industri lain sangat besar sehingga berpengaruh terhadap keberlanjutan industri. Pendekatan yang digunakan untuk menentukan nilai pendapatan tenaga kerja 
adalah potensi pendapatan rata-rata yang diperoleh oleh setiap karyawan termasuk pendapatan tambahan yang umumnya diterima sebagai insentif. Pendapatan tersebut selanjutnya dibandingkan nilainya dengan nilai Upah Minimum Regional (UMR) yang berlaku. Mutu produk didasarkan pada perspektif kualitas produk. Produk dinyatakan bermutu apabila mempunyai kualitas yang tinggi dan cacat produk yang rendah. Cacat produk yang rendah menunjukkan bahwa produk telah diproses menurut Standard Operating Procedure (SOP) secara baik dan benar. Semakin banyaknya industri alas kaki yang menghasilkan alas kaki membuat persaingan pasar dibidang alas kaki semakin ketat. Kemudahan akses pasar akan mempengaruhi terget penjualan industri alas kaki yang akan juga menentukan keuntungan yang didapat oleh industri alas kaki.

Kerusakan lingkungan akibat sudah menjadi rahasia umum yang harus segera diperhatikan dan diperbaiki, khususnya oleh industri sebagai pengguna sumber daya alam dengan kuantitas yang banyak. Usaha alas kaki merupakan salah satu usaha yang banyak menggukana sumberdaya yang berasal dari alam. Banyak investasi yang bisa dilakukan untuk mengurangi kerusakan lingkungan, seperti menggunakan bahan baku yang sudah memiliki sertifikasi berkelanjutan, menggunakan mesin atau teknologi dengan sumber energi yang ramah lingkungan dan lain sebagainya. Dengan melakukan investasi untuk perbaikan lingkungan menunjukkan bahwa usaha alas kaki bukan hanya memproduksi alas kaki tetapi juga mendukung perbaikan lingkungan.

Alas kaki merupakan produk yang bersifat dinamis dan selalu berkembang mengikuti perkembangan jaman. Perubahan mode yang sedang banyak dinikmati akan mengubah jenis dan alas kaki yang dinikmati. Perubahan jenis dan bentuk alas kaki biasanya diikuti oleh perubahan bahan dan teknologi yang digunakan. Oleh karenanya, usaha alas kaki harus selalu mengikuti perkembangan khususnya dibidang teknologi dan bahan yang digunakan. Pengembangan teknologi bisa didapatkan dengan cara melakukan penelitian dibidang alas kaki atau dengan mengikuti pelatihan dan bazar mengenai alas kaki.

Nilai indeks keberlanjutan dimensi ekonomi, posisi IKM alas kaki berada pada adalah 33,623 dan termasuk dalam kategori kurang berkelanjutan yang ditunjukkan oleh Gambar 1. Hasil perhitungan menunjukkan Nilai S-stress yang didapat sebesar 0,162 dan RSQ sebesar 0,945, sehingga model yang digunakan dapat mempresentasikan permasalahan yang sedang terjadi di industri alas kaki. Analisis leverage untuk dimensi ekonomi pada Gambar 2 menunjukkan indikator yang sensitif dan bisa meningkatkan nilai indeks keberlanjutan apabila dilakukan perubahan adalah akses pasar dan pendapatan tenaga kerja.

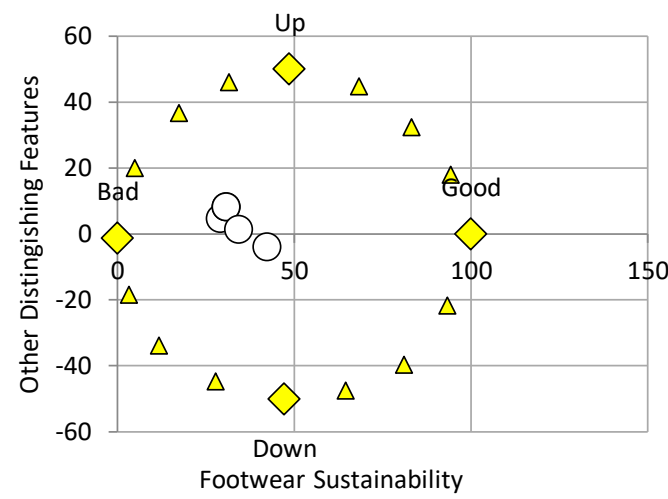

Gambar 1. Rap-analysis Dimensi Ekonomi

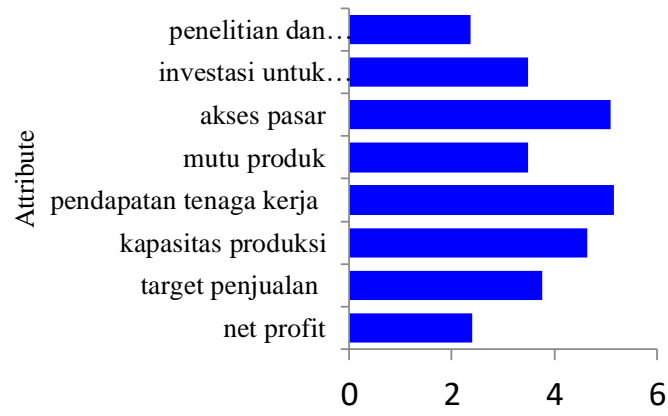

Root Mean Square Change \% in Ordination when Selected Attribute Removed (on Status scale 0 to 100)

Gambar 2. Leverage Footwear dimensi ekonomi

\section{Dimensi Sosial}

Menurut Saeed dan Karsten (2017), dimensi sosial menggambarkan cara organisasi organisasi bertanggungjawab secara sosial dan mengatur sumberdaya manusia yang dimiliki. Keberlanjutan dimensi sosial terdiri atas 8 indikator, yaitu: 1) peluang bagi tenaga kerja lokal; 2) keterampilan SDM; 3) kemudahan akses kesehatan; 4) penggunaan alat keselamatan kerja; 5) kualitas tempat kerja; 6) pelatihan tenaga kerja; 7) jumlah produk dikembalikan; dan 8) kesesuaian dengan peraturan ketenagakerjaan. Hak asasi manusia dan anti korupsi menggambarkan informasi tentang korupsi dan pelanggaran terhadap hak asasi manusia, yang ditunjukkan oleh adanya diskriminasi, pemaksaan dan penggunaan anak sebagai pekerja, serta pelanggaran terhadap kebebasan. Industri alas kaki khususnya skala usaha kecil atau IKM merupakan usaha turun temurun di suatu kawasan. Industri alas kaki apabila berproduksi dalam kapasitas optimal dapat menyerap banyak tenaga kerja karena bersifat padat karya. Hampir semua kegiatan produksi menggunakan tenaga manusia baik untuk bekerja secara manual, maupun untuk mengontrol mesin yang digunakan.

Tenaga kerja lokal adalah pekerja yang berasal dari wilayah disekitar industri alas kaki. 
Dengan menyerap tenaga lokal akan menunjukkan kemudahan dalam mendapatkan tenaga kerja dan membantu mengurangi pengangguran. Ketrampilan SDM atau tenaga kerja menjadi salah satu indikator keberlanjutan dimensi sosial karena berpengaruh besar terhadap perbaikan kinerja industri. Purnomo (2012) mengasumsikan bahwa nilai ketrampilan SDM (poin skill) maksimal yang mampu dicapai adalah 12. Nilai tersebut kemudian diklasifikasikan. Klasifikasi tersebut akan berpengaruh terhadap tingkat kecacatan produk dan produktivitas tenaga kerja. Dengan karakteristiknya yang banyak bertumpu kepada tenaga kerja manusia, terjadinya peningkatan ketrampilan SDM tentunya akan berdampak terhadap peningkatan kinerja pada dimensi lainnya secara nyata. Dari sisi tenaga kerja, pada dasarnya, ketrampilan adalah keahlian yang diperoleh oleh tenaga kerja yang bekerja pada suatu industri. Keahlian tersebut merupakan modal bagi tenaga kerja karena dengan bekal tersebut timbul prestasi dan penghargaan kerja. Industri alas kaki menggunakan lem dan proses pemanasan untuk merekatkan lem dalah menghasilkan produknya.

Pemasan lem menggunakan mesin yang harus dikontrol secara manual. Penggunaan lem membuat ruangan produksi memiliki bau khas yang menyengat dan bisa membahayakan para pekerja. Hasil kunjungan ke beberapa industri alas kaki menunjukkan bahwa pekerja jarang menggunakan masker sebagai pelindung organ pernapasan. Pekerjapekerja yang mengoperasikan mesin pemanas tidak menggunakan sarung tangan sebagai pelindung. Kemudahan akses kesehatan bagi tenaga kerja menunjukkan bahwa industri alas kaki sangat memperhatikan kesehatan para pekerja, yang akan menentukan keberlanjutan industri alas kaki dalam dimensi sosial. Sebab bukan tidak mungkin kecelakaan dalam bekerja membuat tenaga kerja memilih untuk pindah dari industri alas kaki. Produk alas kaki menggunakan lem untuk menempelkan bagian-bagiannya, dan biasanya lem yang digunakan memiliki bau yang menyengat. Oleh karenanya, dibutuhkan masker atau pelindung mulut dan hidung untuk menghirup bau tersebut. selain itu, di pabrik alas kaki setelah lem diberikan pada bagian alas kaki kemudian dilanjutkan dengan pamanasan. Pabrik alas kaki yang menghasilkan sol juga menggunakan mesin pencetak dan pres yang cukup panas.

Pada IKM peran mesin pres digantikan oleh martil untuk memukul secara manual bagian alas kaki yang akan direkatkan. Oleh karenanya, diperlukan alat pelindung untuk menjaga keselamatan pekerja. Berdasarkan kunjungan yang telah dilakukan, usaha alas kaki memiliki ruangan yang terdiri dari ruangan produksi, gudang penyimpanan, dan ruangan kantor. Kualitas tempat kerja dinilai secara keseluruhan. Semua kegiatan IKM dilakukan dalam satu ruangan, padahal bau menyengat dan kotoran-kotoran yang berasal dari ruangan produksi dapat mengganggu. Penggunaan lem yang memiliki bau menyengat dapat mengganggu pekerja dan bisa menimbulkan dampak kesehatan.selain itu, penggunaan mesin juga menyebabkan udara diruangan produksi menjadi lebih panas. Alas kaki merupakan salah satu bagian dari fashion yang cepat sekali mengalami perubahan, sehingga industri alas kaki harus selalu mengikuti perubahan untuk terus dapat bersaing. Perubahanperubahan alas kaki tentunya akan merubah bahan, proses dan teknologi yang digunakan untuk menghasilkan alas kaki. Kemampuan tenaga kerja untuk mengikuti perubahan juga akan menentukan kualitas alas kaki yang dihasilkan. Oleh karenanya, pelatihan tenaga kerja mengenai trend alas kaki terbaru menjadi penting untuk dilakukan agar produk yang dihasilkan laku di pasaran.

Kepemilikan sertifikasi dalam bidang sosial menunjukkan bahwa organisasi tersebut memiliki kesadaran untuk mengatur sumberdaya manusia yang dimiliki. Sertifikasi juga menunjukkan bahwa manajemen sumberdaya manusia yang dilakukan dalam organisasi tersebut sudah baik dan memiliki standar yang jelas, sehingga pelanggaran terhadap hak-hak pekerja tidak ditemukan. Nilai indeks keberlanjutan dimensi sosial IKM alas kaki adalah 36,298 dan termasuk dalam kategori kurang berkelanjutan yang ditunjukkan oleh Gambar 3.

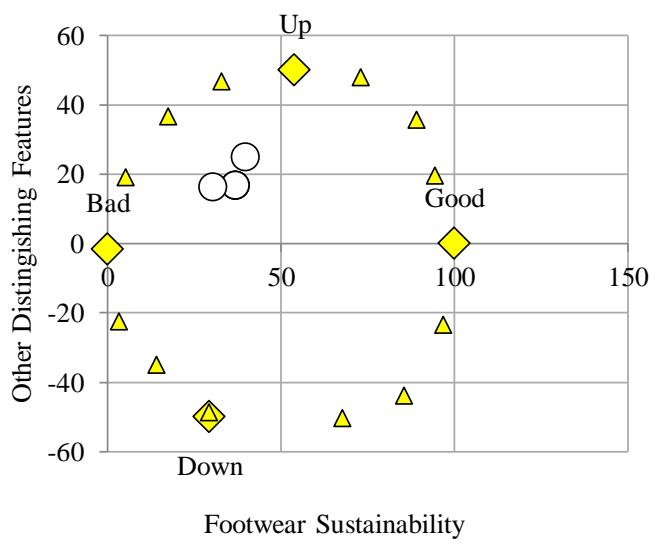

Gambar 3. Rap-analysis Dimensi Sosial

Hasil perhitungan menunjukkan Nilai $\mathrm{S}$ stress yang didapat sebesar 0,154 dan RSQ sebesar 0,932, sehingga model yang digunakan dapat mempresentasikan permasalahan yang sedang terjadi di industri alas kaki. Analisis leverage untuk dimensi sosial pada Gambar 4 menunjukkan indikator yang sensitif dan bisa meningkatkan nilai indeks keberlanjutan apabila dilakukan perubahan adalah kualitas tempat kerja dan penggunaan alat keselamatan kerja.

\section{Dimensi Lingkungan}

Dimensi lingkungan menggambarkan perilaku industri dalam menjaga dan melestarikan lingkungan di sekitarnya. Dengan begitu, industri bukan hanya memproduksi produk yang dihasilkan, tetapi juga ikut memikirkan bagai mana cara 
melestrarikan dan mengurangi dampak negatif yang ditimbulkan dari produk yang dihasilkan. Akan tetapi, keberlanjutan dimensi lingkungan pada industri alas kaki memiliki indikator yang sangat terbatas. Keberlanjutan dimensi lingkungan terdiri atas 6 indikator, yaitu: 1) pengurangan jumlah energi terpakai; 2) penggunaan bahan baku ramah lingkungan; 3) tingkat pengelolaan limbah; 4) pengukuran dan pengurangan emisi; 5) sertifikasi dalam bidang lingkungan; dan 6) penggunaan bahan dari pemasok lokal. Hal tersebut terjadi karena industri alas kaki adalah industri padat karya yang lebih banyak menggunakan tenaga manusia dibandingkan dengan sumber-sumber energi.

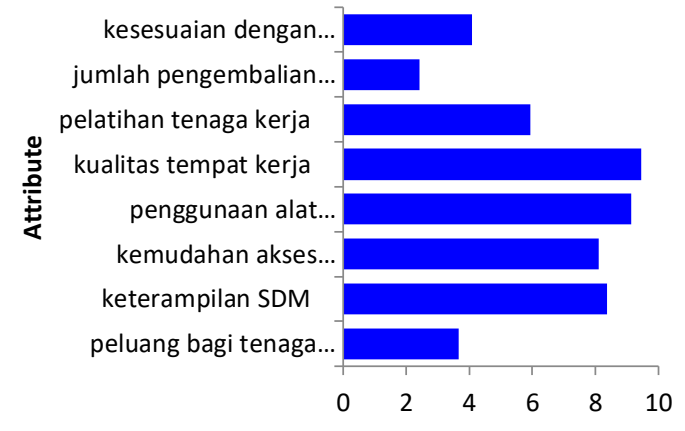

Root Mean Square Change \% in Ordination when Selected Attribute Removed (on Status scale 0 to 100)

Gambar 4. Leverage Footwear dimensi sosial

Industri alas kaki menggunakan mesinmesin dengan sumber energi berupa listrik. Selain itu, ruangan produksi harus memiliki penerangan yang cukup agar pekerja dapat melihat alas kaki dengan mudah dan proses produksi berjalan dengan lancar. Padahal, penggunaan energi listrik merupakan salah satu penyumbang kerusakan lingkungan. Oleh karenanya, untuk mencapai alas kaki berkelanjutan harus memikirkan cara yang bisa dilakukan untuk mengurangi penggunaan energi listrik. Kerusakan lingkungan akibat sudah menjadi rahasia umum yang harus segera diperhatikan dan diperbaiki, khususnya oleh industri sebagai pengguna sumber daya alam dengan kuantitas yang banyak. Salah satu cara yang bisa dilakukan oleh industri alas kaki adalah dengan menggunakan bahan baku yang sudah memiliki sertifikasi berkelanjutan. Sebab, bahan baku industri alas kaki kebanyakan berasal dari alam. Dengan menggunakan bahan baku yang sudah memiliki sertifikasi berkelanjutan menunjukkan bahwa produk yang dihasilkan oleh industri alas kaki mendukung perbaikan kerusakan lingkungan. Limbah yang dihasilkan oleh industri alas kaki berupa limbah padat hasil pemotongan bahan.

Hasil penelitian pendahuluan di beberapa industri alas kaki menunjukkan limbah padat tersebut masih ada yang bisa digunakan oleh industri alas kaki dengan skala yang lebih kecil, diolah kembali atau digunakan sebagai bahan bakar industri lainnya.
Sumber energi yang digunakan oleh pabrik dan IKM alas kaki sebagian besar berasal dari listrik. IKM juga ada yang menggunakan gas elpiji sebagai sumber energi. Proses distribusi produk yang termasuk dalam bagian rantai pasok menggunakan bahan bakar untuk menjalankan kendaraan. Semua sumber energi tersebut menghasilkan emisi yang memberikan dampak bagi lingkungan. Oleh karenanya, diperlukan pengelolaan dan pengurangan emisi yang dilakukan dengan mengurangi jumlah energi yang digunakan, sehingga usaha alas kaki dapat menjaga kelestarian lingkungan. Permintaan akan produk yang memiliki sertifikasi dibidang lingkungan, contohnya ekolabel semakin meningkat.

Beberapa negara di Eropa dan Amerika sudah mensyaratkat produsen untuk memiliki ekolabel pada produknya jika ingin produknya dipasarkan di negara tersebut. pabrik dan IKM alas kaki yang sudah diamati belum memiliki sertifikasi dibidang lingkungan. Oleh karenanya, usaha alas kaki di Indonesia harus mulai memikirkan sertifikasi agar produk yang dihasilkan dapat memiliki pasaran yang luas dan dapat bersaing dengan produsen lain. Usaha alas kaki membutuhkan bahan baku seperti, kain dan kulit untuk bagian atas alas kaki dan khususnya bagian sol yang menjadi fokus dari penelitian ini. Bahan-bahan tersebut ada yang didapatkan dari pabrik lokal dan juga dari pabrik internasional. Untuk IKM, bahan-bahan yang digunakan berasal dari toko di sekitar kawasan IKM dan asal dari bahan di toko tersebut sulit untuk ditelusuri. Penggunaan bahan yang berasal dari lokal membaut jarak tempuh dalam mendistribusikan bahan lebih sedikit dibandingkan dengan penggunaan bahan yang berasal dari internasional, yang akan sebanding dengan emisi yang dihasilkan. Semakin jauh jarak distribusi bahan maka semakin banyak emisi yang dihasilkan, yang akan berdampak pada kerusakan lingkungan yang ditimbulkan.

Nilai indeks keberlanjutan dimensi lingkungan IKM alas kaki adalah 24,995 dan termasuk dalam kategori tidak berkelanjutan yang ditunjukkan oleh Gambar 5. Hasil perhitungan menunjukkan Nilai S-stress yang didapat sebesar 0,134 dan RSQ sebesar 0,933, sehingga model yang digunakan dapat mempresentasikan permasalahan yang sedang terjadi di industri alas kaki. Analisis leverage untuk dimensi lingkungan pada Gambar 6 menunjukkan indikator yang sensitif dan bisa meningkatkan nilai indeks keberlanjutan apabila dilakukan perubahan adalah tingkat pengelolaan limbah, pengukuran dan pengurangan emisi.

Kategori keberlanjutan dimensi ekonomi dan sosial IKM alas kaki adalah kurang berkelanjutan. Indikator yang berpengaruh untuk meningkatkan indeks untuk dimensi ekonomi akses pasar dan pendapatan tenaga kerja dan untuk dimensi sosial berdasarkan analisis leverage adalah kualitas udara ruangan produksi dan penggunaan alat keselamatan kerja. Kategori keberlanjutan 
lingkungan di IKM alas kaki termasuk dalam kategori tidak berlanjut dengan analisis leverage yang menunjukkan indikator yang sensitif dan perlu dilakukan perbaikan adalah tingkat pengelolaan limbah; pengukuran dan pengurangan emisi.

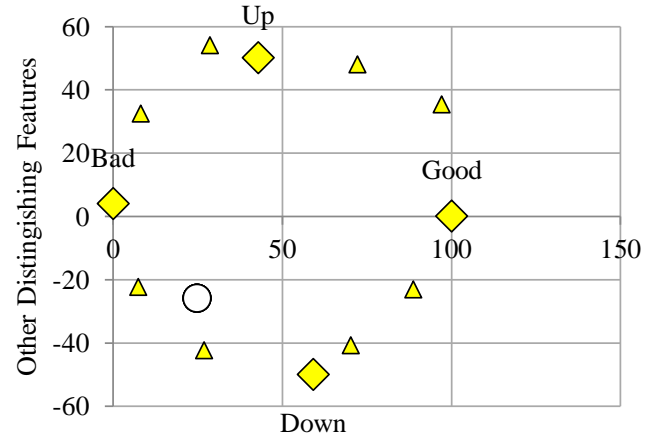

Footwear Sustainability

Gambar 5. Rap-analysis Dimensi Lingkungan

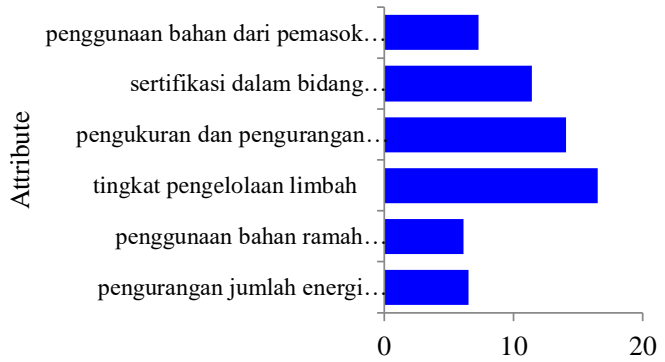

Root Mean Square Change \% in Ordination when Selected Attribute Removed (on Status scale 0...

Gambar 6. Leverage Footwear Dimensi Lingkungan

Kategori keberlanjutan dimensi ekonomi dan sosial IKM alas kaki adalah kurang berkelanjutan. Indikator yang berpengaruh untuk meningkatkan indeks untuk dimensi ekonomi akses pasar dan pendapatan tenaga kerja dan untuk dimensi sosial berdasarkan analisis leverage adalah kualitas udara ruangan produksi dan penggunaan alat keselamatan kerja. Kategori keberlanjutan lingkungan di IKM alas kaki termasuk dalam kategori tidak berlanjut dengan analisis leverage yang menunjukkan indikator yang sensitif dan perlu dilakukan perbaikan adalah tingkat pengelolaan limbah; pengukuran dan pengurangan emisi.

Tabel 2. Keberlanjutan rantai pasok

\begin{tabular}{lc}
\hline Dimensi & $\begin{array}{c}\text { Indeks Keberlanjutan Rantai } \\
\text { Pasok IKM alas Kaki }\end{array}$ \\
\hline Ekonomi & Kurang berlanjut $(33,623)$ \\
Sosial & Kurang berlanjut $(36,298)$ \\
Lingkungan & Tidak berlanjut $(24,995)$ \\
\hline
\end{tabular}

\section{Keterbatasan Penelitian}

Penelitian ini memiliki keterbatasan dalam rantai pasok. Penilaian yang diukur masih terbatas pada pengrajin sebagai pelaku didalam membuat alas kaki yang berada ditiga kecamatan Bogor.

\section{KESIMPULAN DAN SARAN}

\section{Kesimpulan}

Pengukuran keberlanjutan menggunakan 3 dimensi, yaitu dimensi ekonomi yang terdiri dari delapan indikator, dimensi sosial terdiri dari delapan indikator dan enam indikator untuk dimensi lingkungan. Hasil pengukuran indek keberlanjutan masih belum mencapai indeks berlanjut untuk ketiga dimensi. Masih perlu dilakukan perbaikan pada indikator akses pasar dan pendapatan tenaga kerja pada dimensi ekonomi. Pada dimensi sosial, perbaikan perlu dilakukan pada indikator kualitas udara ruangan produksi dan penggunaan alat keselamatan kerja. Indikator yang perlu dilakukan perbaikan pada dimensi lingkungan adalah tingkat pengelolaan limbah, pengukuran dan pengurangan emisi.

\section{Saran}

Untuk meningkatkan indeks keberlanjutan alas kaki di Kabupaten dan kota Bogor, diperlukan kerjasama antara pelaku usaha, universitas, balai penelitian, dan pemerintah agar terjadi keberlanjutan yang bersinergi.

\section{DAFTAR PUSTAKA}

Ageron B, Gunasekaran A, dan Spalanzani A. 2011. Sustainable supply management: an empirical study. International Journal Production Economics, Article in press.

Alder J, Pitcher TJ, Preikshot D, Kaschner F. 2000. How good is good? a rapid appraisal technique for evaluation of the sustainability status of fisheries of the north atlantic. In Pauly and Pitcher (Eds.) Methods for Evaluation the impacts of fisheries on the north atlantic ecosystem. Fisheries Research Report. 8(2).

Batubara SC. 2016. Desain sistem manajemen rantai pasokan industri perikanan tangkap laut berkelanjutan. [Disertasi]. Bogor: Institut Pertanian Bogor.

Fauzi A dan Anna S. 2002. Evaluasi status keberlanjutan pembangunan perikanan: aplikasi pendekatan Rapfish (studi kasus perairan pesisir DKI Jakarta). Jurnal Pesisir \& Lautan. 4(3):43-55.

Herva M, Álvarez A, dan Roca E. 2011. Sustainable and safe design of footwear integrating ecological footprint and risk criteria. Journal Hazardous Materials. 192(3):1876-1881.

Kavanagh P dan Pitcher TJ. 2004. Implementing Microsoft Excel Software For Fish: A Technique For The Rapid Appraisal Of Fisheries Status. Fisheries Centre. Canada :University of Columbia. 
Kholil, Dharoko TA, dan Widayati A. 2015. Pendekatan multi dimensional scaling untuk evaluasi keberlanjutan Waduk Cirata Propinsi Jawa Barat. Jurnal Manusia dan Lingkungan. (1) : 22-31

Müller M dan Seuring S. 2008. From a literature review to a conceptual framework for sustainable supply chain management. Journal Cleaner Production. 16:1699-1710. https://doi.org/10.1016/j.jclepro.2008.04.020.

Allahyari MS. 2010. Fisheries sustainability assessment in guilan district and city Iran. Journal Food, Agriculture \& Environment. 8(3\&4): 1300-1304.

Nurmalina R. 2008. Analisis indeks dan status berkelanjutan sistem ketersediaan beras di beberapa wilayah Indonesia. Jurnal Agro Ekon. 26(1):47-49.

Nurzamzami A dan Siregar EH. 2014. Peningkatan daya saing UMKM alas kaki di kecamatan Ciomas, kabupaten Bogor dan implikasinya terhadap strategi pemasaran. Jurnal Manajemen dan Organisasi. V(1): 15-29.

Purnomo BH. 2012. Rancang bangun model prediksi keberlanjutan agroindustri perikanan tangkap. [Disertasi]. Bogor: Institut Pertanian Bogor.

Reise C dan Phan L. 2016. Sustainable Manufacturing in Vietnamese Engineering Education - Approaches from the VietnameseGerman University. Procedia CIRP. 40: 341346. doi 10.1016 .
Saeed MA dan Kersten W. 2017. Supply chain susainability performance indicators - a content analysis based on published standarts and gudelines. Logistic Research. 10 (12): 119. doi 10.23773 .

Sarma MD, Farida RS, dan Edward H. 2014. Pengembangan Industri Kecil dan Rumah Tangga Alas Kaki dalam Menuju Keberlanjutan Usaha dan Menghadapi ChinaASEAN Free Trade Agreement. Manajemen IKM. 9(1): 67-75.

Seuring S. 2012. A review of modeling approaches for sustainable supply chain management. Decision Support Systems, Article in Press.

Sriwana IK. 2016. Rancang bangun model rantai pasok agroindsutri kakao berkelanjutan dengan menggunakan sistem cerdas. [Disertasi]. Bogor: Institut Pertanian Bogor.

Subic A, Shabani B, Hedayati M, Crossin E. 2012. Capability framework for sustainable manufacturing of sports apparel and footwear. Sustainability 49(9): 2127-2145, doi 10.3390.

Thanh Phan XT, Pham CH, dan Pham L. 2016. The Competitive advantages of vietnam footwear industry: An Analysis. International Journal Financial Research. 7(3): 65-80, doi 10.5430. 